\title{
Gender as Site of Power Enactment in The Power of Um and The Reign of Wazobia
}

\author{
Eunice Fonyuy Fondze-Fombele \\ University of Buea, Buea, Cameroon
}

\begin{abstract}
This study discusses how Liking (1996) in The Power of Um and Onwueme (1992) in The Reign of Wazobia anchor complex negotiations of public and private identities on gender as a site of enactments of power. Through experimentation with dramatic techniques, the selected Cameroonian and Nigerian women playwrights emphasize the centrality of gender as a site for a sustained critique of the larger social formations. The paper hypothesizes that Liking's and Onwueme's plays are thematically ambitious and stylistically experimental demonstrating a dynamic process through which the dramatists integrate concrete experiences into their creative consciousness in gender-conscious ways. In that respect, gender stands out as the performance space of struggle between the performance of power to maintain hegemony and the power of performance for social change. For scientific vigour, the study uses the gender relations approach to demonstrate how the playwrights appropriate the dynamics of performance to translate, interpret and challenge deeply ingrained patriarchal paradigms and also to explain, theorize and account for the complex realities of African women's lives.
\end{abstract}

Keywords: gender, enactments of power, performance techniques, social change

\section{Introduction}

The concept of gender has not only informed many sociological, developmental and literary discourses in Africa, but like many other concepts emanating from the West, it has generated a lot of controversy. A growing body of discourses on gender in Africa challenge the misconstruing of the nature of gender and gender relations in Africa, perspectives that heavily rely on Western feminist and gender discourses (Moore, 1995; Ogundipe-Leslie, 1994). Oyewumi (1997) uses the Yoruba case study to demonstrate how the social category men and women were nonexistent; hence no gender system was in place. She contends that the primary principle of social organisation was seniority, defined by relative age. Also, Sudarkasa (1986) asserts that reading African lives through the lens of gender works to conceal other important social and cultural axis of differentiation like issues of ageism and wealth. The above arguments are significant because they caution against superimposing meanings derived from Western thoughts on discussions of African women's experience. However, there has been a shift in perspective as some African literary scholars have captured the usefulness of gender as a category of analysis (Nnaemeka, 1997; Nfah-Abbenyi, 1997; Cornwall, Harrison, \& Whitehead, 2004). Also, the focus on 
gender as a category of analysis in African literature has been tilted more towards the novel, yet some critics raise the significance of performed genres as the best medium and catalysts for political praxis and social change (Gunner, 1995; Sahli, 1998; Kruger, 1999; Gigandi, 2002). In addition, Mule (2007, p. 5) has posited that "the race for mastery of the most current critical idiom seems at the moment unavoidable, and the novel enjoys supremacy as the object of contemporary cultural, theoretical, and literary reflection”. She goes further to posit that "as an unintended consequence, scholars of African literature have largely ignored modern African women's drama”. The present study forms part of the contribution to address this gap as it chooses African women's plays whose performance space spins on the axis of gender from where stems complex negotiations of public and private identities.

The term gender is defined and used for the purpose of this study as the condition and experience of being men as a sex and of being women as a sex in a particular setting. It takes into cognizance the fact that women have been the main victims of male supremacist tendencies and so have been defined and positioned on the lowest ranks of all gender attributes, roles and responsibilities. The paper hypothesizes that Liking's and Onwueme's plays are thematically ambitious and stylistically experimental, demonstrating a dynamic process through which the playwrights integrate concrete experiences into their creative consciousness in gender-conscious ways. The aim of this study therefore is to demonstrate how the selected women dramatists use the power of performance to (re)interpret the dynamics of gender as a space of performance. The analysis has two research questions: How do the playwrights use gender as a space of performance to oppose and contest specific social arrangements? What performance strategies and how are they used in negotiating complex public and private identities? To answer these questions, the analysis explores women's multiple social identities and identifications.

To take multiple social, private and public identities and identifications of women to consideration calls for an approach that is sensitive to the range of relational subject positions taken up by women and men in the different domains of discourse that co-exist within any single cultural setting. The gender relations approach, which is concerned with how power is distributed between the sexes and how power relations "create and reproduce systemic differences in men's and women's positions in a given society” (March, Smyth, \& Mukhopadhyay, 1999, p. 18) is used for analysis. According to March et al. (1999, p. 18) gender relations are simultaneously relations of cooperation, connection, and mutual support, and of conflict, separation, and competition, of difference and inequality. Gender relations vary according to time and place, between different groups of people, and according to other social relations like class, race, ethnicity, disability and so on. Therefore, the condition of being of African men and women, because of their cultural, social and historical specificities, is necessarily peculiar and this peculiarity can best be analysed in the (con)text of performance. The theory and practice of gender relations proceed as an ethical imperative, in the interest of women because women are the chief victims of male domination as a system of meanings and values and power relations. The women dramatists' task is to pin their politics on gender and provoke a space of performance that can impel the recognition of women's importance, worth and human dignity and create and maintain possibilities for genuinely humane choices for women.

\section{Gender as a Site of Enactments of Power}

The Cameroonian Liking's and Nigerian Onwueme's respective plays The Power of Um and The Reign of 
Wazobia use remarkable artistic experimentation through the domain of gender to stimulate positive change. The two plays constitute some of the clearest and boldest statements about the concerned playwrights' gender and feminist vision of social transformation, particularly with regards to some vexing questions about African women's existential realities in their social relations with men and with the community. The driving force in the plays is the immediate concern with the specific conditions of women as a social constituency and as a political one demanding a resolution. Interestingly, the two playwrights anchor the performance on a mundane, though horrific issue that affects women, the torments of incessant funerary rites that widows are subjected to and from which men are free under similar circumstances. That is to say in the plays the dramatic conflict and tension that provokes enactments of power begins with women's refusal to participate in the funerary rites befitting the burial of their husbands. This power struggle is seen in the plays through the social relations of performance of power by patriarchal and traditional hegemony in opposition with the power of performance by women like Ngon Libii in The Power of Um and Wazobia in The Reign of Wazobia.

Liking in The Power of Um centres the dramatic conflict on the character of Ngond Libii, the widow of Ntep Iliga who happens to be a very important personality, a man considered as a "respectable" leader by the community. Particularly, the crisis in the plot of the play stems from Ngon Libii's actions as she confronts the entire community with her awkward but self-conscious attitude towards her husband's burial process. Set within the context of the funerary rites upon the death of Ntep Iliga, the performance context demonstrates gender as a site of enactments of power in the play. THIRD MAN's pronouncements are revealing of traditional beliefs that put women in the same rank with animals and things:

THIRD MAN: The funeral will start with great pomp tonight. Our most venerable comrade will rest on five rams, seven pigs and nine cocks; there will also be for the comfort of his venerable corpse, the body of his beloved wife whom he has never stopped loving in spite of her doubtful origin and her lowly condition. Let us not separate them, for what God has put together, let no man put asunder. (p. 49)

Since the dead man, Ntep Iliga was an important and propertied man in his community, he must be buried with part of his property including well selected healthy animals, one or more of his slaves and his favourite wife as tradition requires. Tradition becomes a site of performance of power on women and animals. The fact that the surviving widow is buried alongside her husband demonstrates her social relation with members of the community who clothe themselves in the cloak of traditionalism; a tradition that considers only the man's dignity even in his grave, at the detriment of the dignity of the widow. Even so, according to tradition, the widow must hold on to stringent taboos including isolation and lack of communication with the outside world except through older widows, who are her initiators into widowhood:

OLD WOMAN: For nine days following your husband's death, you will answer no call. If somebody insists, answer him: "what do you want from me?" And in order that you may hear the fewest possible calls, clay is put in your ears. During the same period, you will cover yourself with ashes only, for you are mourning your lord and master who will for a long time offer you no clothes. The mourning rope will keep you by the side of your children. (p. 36)

The performance of power on the woman is therefore exhibited through isolation, barring her from communicating with the outside world, refusal of freedom of movement by use of the mourning rope and above all, the fact that she can be buried alongside her husband for the dignity of his corps. 
On her part, Ngon Libii challenges members of the community to unclothe themselves of that cloak of traditionalism through her refusal to shroud herself in a widowhood that places no value on her worth and dignity as a human being. She has borne years of humiliation, sexual exploitation and neglect throughout her life as a wife so as to protect her husband's reputation because he was considered a "respectable" leader. His death then produces an opportunity for her to emerge from her servile domesticity to become an important agent in the process of reshaping her political community. According to the belief system, the death of the husband does not just happen; it is always caused by someone and the community resorts to a formal procedure for finding the killer of Ntep Iliga, "The murderer of Ntep will jump over the animals and only then will we lay Ntep to rest comfortably as his rank requires” (p. 38). The community’s belief system projects a myth that upon the death of a husband, the first accusing finger is always pointed at the widow. Since the wife is the first accused, the mourners are expecting Ngond Libii to go through the humiliating funerary rites of wifely confession in order to give her husband a decent burial deserving of his status. Ngond Libii's situation is aggravated by the fact that she is of a questionable background, "there will also be for the comfort of his venerable corpse, the body of his beloved wife whom he has never stopped loving in spite of her doubtful origin and her lowly condition” (p. 49). According to the community's standards, Ngon Libii was of a low social status and her marriage to Ntep Iliga was nothing other than a display of his magnanimity.

Liking uses the occasion of funerary rite that brings together the whole community as a space to demonstrate enactments of power in gender-conscious ways. Ngon Libii antagonistically rejects the performance of power on her and in turn uses the funerary rite as a site of the power of performance to provoke social change. Ngon Libii does not only refuse to go through the funerary rite and accord Ntep Iliga that honour he presumably deserves from his widow; she further surprises the mourners when she insists on a quick burial and also claims responsibility for her husband's death. She unapologetically declares:

Were he to have nine lives, I would kill him nine times! I will kill him in my heart which has never stopped loving him. I will kill him. Here in my body which has not stopped trembling at the thought of him, I will kill him. There in the memory of our common dreams which are still dreams, I will kill him. Here in all the smothered talents, there in all the untapped life-springs that have been dragged through rot, I will kill him. Bury him! Why would I cry? Bury and come feast. . . (She resumes pounding). (Liking, 1996, p. 44)

Her declarations in the above quotation reveal the irony behind the performance of power by tradition. Since in the community's belief system she is expected to do a wifely confession, she tells the mourners to their faces what they belief but do not expect her to openly pronounce in the circumstances of the funeral. Through the repetition of "I will kill him" Ngond Libii insistently reminds the community of the woes of women who are always considered potential murderers of their spouses. Ngon Libii's performance space in the play becomes a space of the power of performance as opposed to that of performance of power by tradition and patriarchal hegemony. Ngugi (2002) defines the power of performance as follows:

Performance is representation of being, the coming to be, and the ceasing to be of processes in nature, human society, and thought. If before the emergence of the state the domain of culture embodied the desirable and the undesirable in the realm of values, this was expressed through performance. The community learnt and passed on its moral codes and aesthetic judgements through narratives, dances, theatre, ritual, music, games and sports. (p. 37)

Through the power of performance exhibited by the woman Ngon Libii, new meaning is given to wifehood 
and widowhood which should cease to be in a state of complete and perpetual dependency on the husband, whether dead or alive. This means that Ngond Libii's refusal to clothe herself in the cloak of widowhood becomes a challenge to social attitudes towards wifehood and widowhood, two roles that are fundamental in shaping African women's attitudes towards themselves and towards their social, economic and political development. The power of performance is further seen in the manner the dramatist constructs her characters, with the purpose of making her audiences reflect on their own lives. Widows for example can discern not only their trials and tribulations in those of Ngond Libii's but they can also learn that they do not need to be enslaved by tradition. This challenge to social attitudes is also the concern of the enactement of power in Onwueme's The Reign of Wazobia.

In The Reign of Wazobia, the main conflict stems from the fact that under Wazobia's rule as regent in the Kingdom of Anioma, she checks, scrutinizes and publicly rejects certain traditional demands on women, especially those that affect their dignity as wives, widows and as human beings. One of such checks is when Wazobia refuses to enforce the law that warrants for a woman to go through a humiliating rite of public confession upon the death of her husband. The situation in The Reign of Wazobia is also sensitive because the person who has died is the King, a man and very important personality. Omu who in the Igbo cultural community in which the play is set is recognised as the undisputed leader of women—-the female "king"—-takes upon herself to implement the funeral rite. To her surprise, the widows of the late King fail to show up and go through the rite. The Omu is left with no option than to confront Wazobia who now occupies the royal throne of Anioma. The dialogue that ensures between the Wazobia and the Omu in Movement Two is revealing of Wazobia’s position on women's conditions in her community. Wazobia questions and condemns this aspect of tradition that degrades the woman's dignity:

OMU: ...

Why, King

Do these women

Sit here at the level of the throne while the Chiefs and the entire Kingdom await them to make their appearance at the market-place so as to complete the funeral rites for the King that travelled. Why?

WAZOBIA: Why, may I ask, must widows be subjected to the torment of incessant funeral rites that men are free of, under similar situations, Omu? (Onwueme, 1992, p. 21)

Wazobia firmly refuses to implement an aspect of tradition that is purposefully meant to humiliate and subject women to undignified treatment to which men are exempted in similar circumstances. The Omu's answer to Wazobia's rebuttal is a cause for concern,

It is our tradition that women who survive funeral rituals dance naked in the market-place as final mark of their innocence regarding their husband's death. A woman who dies mourning is unclean and must be left to rot in the evil forest” as a final sign of their innocence and act of cleansing. (Onwueme, 1992, p. 21)

This answer reveals that the wife is always considered a potential murderer of her spouse no matter the circumstances surrounding his death. The inhuman conditions that she is opened to during the ritual process can even cost her life; if she dies she is considered unclean and left to rot in the evil forest. Interestingly enough, the husband does not go through any rite in the event of the death of his spouse because tradition has accorded him a 
human status superior to that of the woman. This demonstrates that gender issues are ingrained in the very fabric of tradition which makes human action to generate gender violence, abuse, assault and even murder. The playwright through performance instructs that tradition should be acquiescent to change.

It is important to underscore here that Wazobia is not rejecting tradition in its entirety, but she is determined to unveil and challenge those fundamentals of tradition that are nothing but a burden to womanhood. As a matter of fact, she unveils the negative tendencies behind such degrading aspects of tradition as she continues to respond to the Omu. "WAZOBIA (Arrogantly) I see, Omu. My women will not dance naked in public to appease the eyes of a wrathful populace. This is no era for dancing to entertain lustful eyes” (Onwueme, 1992, p. 21). Wazobia sees in the funerary rite of confession and cleansing nothing other than voyeuristic and sexually degrading rites, a space of performance of power by traditional hegemony. In this space, women are in Wazobia's words compelled to "dance naked in public to appease the eyes of a wrathful populace" and "to entertain lustful eyes". The dramatist demonstrates through the lexis wrathful and lustful that the performance of power in the space of the funerary rite is problematic because everything works at the expense of women and also because men and the society gain nothing from it apart from the fact that it boosts male supremacist tendencies. The play becomes a call for the society to understand that tradition should be malleable and that those aspects of tradition that have outlived their usefulness should be eradicated. Onwueme uses her play to call on women to be agents of this change as Wazobia's answer to the Omu who insists that she will not be party to "the death of tradition" specifies, "Women, that is the task before you, to set the hand of the clock aright, to move time, not to allow time to move you” (Onwueme, 1992, p. 23).

When the play opens, Wazobia's hold on power is threatened by the male chiefs, led by Iyase, who are on the edge of deposing her. The male chiefs are intimidated by the fact that Wazobia uses her reign as regent to launch attacks on age-long discriminatory practices against women in her community. Iyase's statement during a crucial meeting exemplifies this male discriminatory behaviour on women, particularly when it comes to community affairs. The scene quoted below from Movement Three reveals the gender tussle in the dialogue between Iyase and Wazobia and Idehen:

Iyase: (Standing): Then King, if we must deliberate on such serious state matters, women and the youth must be sent away! (IYASE sits. The men nod their approval)

WAZOBIA: I do not see any reason why women and youths must be kept away from matters of state concern. Matters of state affect them much as they affect chiefs and princes. (The chief and men murmur their discontent; some even whisper to their neighbours)

IDEHEN: I support what my fellow chief, Iyase, has to say. Serious matters of the state concern are too heavy for the brittle heads of women and children. (It is now obvious that women are getting quite uneasy) (Onwueme, 1992, p. 27 emphasis in the original)

The above dialogue portrays in active male supremacist tendencies, the performance of power that have eaten deep into the fabric of the Anioma Kingdom and by extension, into the fabric of the African socio-cultural and political setting. The dialogue demonstrates how women and youths are excluded from serious state matters, a strategy that is meant to silence them and keep them far away from power. The gender tussle in the traditional Inioma society is also revealed in the flashback to Wazobia's coronation ceremony, the Ifejoku. The dialogue between the Priest of Ani and Her Royal Highness the Omu and King of women is telling: 
PRIEST OF ANI: I know the direction of your accusing finger.

Haa Women,

No matter how much you try to elevate them

Never rise above petty squabbles.

OMU: And you call me Woman?

I, the Omu, surpassed all women,

King among women?

PRIEST OF ANI: King among women

But the woman all the same!

No matter how, I still smell woman in you!! (pp. 9-10)

This dialogue demonstrates that traditionally, in power relations between men and women, power is constructed as masculine and when a woman is given a role of responsibility like the Omu, female King, she is still considered less important when the matters of state are being discussed. That is why the priest of Ani further reiterates to the Omu that "since when have women become the pillar of the state? ... Ifejoku is an affair of the land ... It concerns the affairs of the state" (p. 10). Unfortunately for the system, the tradition mandates that upon the dead of the King, a female regent should be appointed in an interregnum. Assisted by chiefs, the regent is supposed to exercise all the sovereign power due to the throne for three seasons before a new King is anointed. Wazobia seizes the opportunity given to her as a regent to present and implement her vision of social change, a project that Ajayi (2002, p. 110) described as "a sustained argument against patriarchal systems that stifle women's potential, breed corruption and lock affected societies into bankrupt traditions and stagnation”. Wazobia's project for change is disclosed at her very first public meeting in the palace. She pronounces:

The King has gathered you to make this pronouncement, that whatever you call yourself, you are, Everyone of You, first and foremost are HUMAN BEINGS with potentials waiting to be actualized for the benefit of this kingdom. ... Henceforth, we all, man and woman, shall have equal rights... none is a slave to another. Man and woman are decreed as partners in progress. (Onwueme, 1992, p. 29)

The power of performance is demonstrated through Wazobia who represents change and does everything possible for women in her regiment to realise the maze they are in and wake up to the call for change. When she becomes regent, in adherence to tradition, she inherits the four wives of the king. The requirements and responsibilities that come with her position as King/husband become strategic because she realises that if she must make a difference in the lives of women in her community, she must start with the women at her court. This action of hers confirms the feminist adage that proclaims the personal as the political. As a dramatist who wants to investigate the conditions under which can emerge a discourse about African women as victims who are also suppose to be agents of social change with a feminist vision, Onwueme strategically puts Wazobia in a real traditional African setting where polygamy and its precarious conditions abound. Women are seen exhibiting traits of jealousy, acrimony and struggle for attention. But wazobia reveals her intention to them when she liberates them from the irrational actions such as grovelling and bowing in order to win the favour of their King and "husband".

Liking and Onwueme as dramatists with a vision for negotiating change through gender as a site of struggle, are very much concerned with the irony of women's situation as custodians, advocates, protectors and defenders of the very same traditions that are manipulated to keep them subjugated and away from power. While Liking in The Power of Um demonstrates a concern for the centrality of women as agents and catalyst of social change, she 
is also interested with the specific issue of women as subjects of malpractices that degrade themselves. Ngond Libii as a wife has unquestionably adhered to customs that reduced her to a prop in Ntep Iliga's drama of life as she worked diligently for the fulfilment of his ego. By having her husband's ego inflated, she participated in causing him to be obsessed with self-importance, repulsively unfeeling, alcoholic, extremely malicious, negligent, profligate and lethargic. In spite of his unbecoming attitude Ngond Libii as a wife continued to heap empty eulogies on him as a descendant of a great line of "respectable" leaders. The result of such empty praises is that Ntep becomes malicious, sexually humiliates and violates Ngond Libii and abandons all his family responsibility as he descends into pathological authoritarianism. That is why when Ngond Libii looks back to her life with Ntep; it is in anger because she comes to the realisation that it has been a life of pain, humiliation, exploitation, assault and violation. If as a wife, Ngond Libii has been an object of sexual gratification and of rejection as she had "to forgive him for having sex in my bed with my friends" (Liking, 1996, p. 42), as a mother she has been reduced to a piece of equipment for breeding children. At this stage of her life she actively allowed Ntep to perform his male dominating power on her. She lived as if she was eager to fulfil the symbolic meaning of her name, "Ngond Libii Ntep Iliga” which according to the dramatist means literally as the slave woman of Ntep Iliga.

The power of performance then takes effect when as a widow she assumes a reflective consciousness. When she rethinks her life with Ntep, she comes to the awareness of the fact that it has been worse than a nightmare. She realises that her docility and her active contribution in the false inflation of his ego has turned him into a monster; the worst that can be made out of a human being. At this moment of reflection and realisation, her story with Ntep becomes to her a "dirty story" (Liking, 1996, p. 35); a life filled with a record of unrestrained behaviour, contemptible gratification, and narcissistic loyalty to self-fulfilling traditions and fanatical hunt of affluence. The aim of the power of performance is to cause the audience to realise that this contemptible life has to cease to be in process. Ngon Libii's assessment of Ntep's life experience with her is in sharp contradiction to the way he is remembered by his obsequious friends like THIRD MAN, for whom he was "a lion of a man” (Liking, 1996, p. 33), the bud of a "great family" and "clan of noblemen" (Liking, 1996, p. 37). The power of performance is discerned when Ngond Libii's refusal to cloak herself in widowhood in honour of a contemptible and assaultive husband sets the stage for an intense gender conflict. Her confrontational behaviour as she refuses to participate in the humiliating funerary rite threatens patriarchal authority and therefore becomes a revolutionary act in gender relations terms.

The irony of women's situation as custodians, advocates, protectors and defenders of the very same traditions that are manipulated to keep them subjugated and away from power can also be detected in Onwueme's The Reign of Wazobia. The Omu in the play particularly represents this type of women whose role is to maintain tradition as it was ordained. Within the Igbo cultural community in which the play is set, the institution of the Omu is distinguished as leader of the women's wing and her position is usually relatively autonomous and powerful in the Kingdom. Ironically, her powerful position does not give her room to work for the best interest of women as a social constituency. Throughout the conflict raised by the widows' failure to perform the funerary rite, the Omu is unnecessarily on the side of tradition notwithstanding what implications such blind adherence to tradition has for women. However, the series of confrontations that she has with Wazobia reveal the enactments of power with gender on the agenda of social change. When Wazobia refuses to let the widows of the late King go 
through the humiliating funerary rites, the Omu maintains the contrary. According to the Omu they must undertake the rite because it is tradition. Her dialogue with Wazobia is revealing of the Omu's position:

OMU: Tradition: Tradition as we met it. Tradition passed down to us from the time when the world's eyes were still closed. Tradition handed down from generation to generation. Tradition... Tradition... tradition...

WAZOBIA: The face of the sun changes, so does the moon.

Seasons too change

So does the face of the clock

The clock ticks... (p. 22)

OMU: I know not clock! Clock know not me!! All I know is time

The intra-gender relations between Wazobia and Omu, particularly in their social relations with tradition are relations of conflict, disconnection and separation. Wazobia represents the voice of change while the Omu wants to allow the crocked hands of tradition to continue to move women. Wazobia warns the women that whether the Omu believes in change or not, there must be change for the Ilaa women of Anioma, in Delta state. She maintains, "You seek to keep the clock stand still, Omu, but gravity must take its toll. I will not be intimidated. For now, that is food enough, chew it” (Onwueme, 1992, p. 23). In other words change must triumph fixity of tradition and time. The performance of power on women is so strong that the Umo does not see the positive transformative reforms instituted by King Wazobia. The Omu, the oldest woman in the land, referred to as "King of Women", is absolutely satisfied with the second fiddle role women play. During the confrontation between Wazobia and the male chiefs who want her deposed, the Omu is decidedly on the side of the male chiefs. To the Omu, Wazobia is just another long-legged and senseless goat from up North who does not understand tradition well enough to rule the kingdom. Nevertheless, the power of performance surpasses the performance of power, for Wazobia's revolutionary policies will mark the end of meanings and values of male domination and emasculation. When Wazobia firmly stands her grounds and persuades other women, the Umo finally sees sense in what she is doing and changes completely.

In the plays' endeavour to communicate the persistent suppression of women and their subjection to some aspects of tradition that have outlived their usefulness, the enactments of power through gender are anchored on the extreme flexibility of the ritual matrix, as medium for articulating a vision of change. The play draws inspiration from the cult of the goddess Um, who according to Kom (1996, p. 10) is considered in the Bassa pantheon as the goddess of tranquillity, peace, and rejuvenation. This goddess is always counted on to restore equilibrium and harmony in times of crisis because she is bestowed with the powers to defend a people of any calamity that befalls them. The argument here is that the use of the traditional elements as aesthetic choices to confront negative gender roles is not in any ways a celebration of return to tradition. Rather, Liking's concern with Bassa ritual and mysticism necessitates that her audience decipher the irony behind the deployment of these Bassa traditions for gender role change. In the space of performance the role of the audience, scene and the caste is so important and helps to reveal how through the complex nature of ritual performance, Liking through the play links traditional cultural practices to issues of gender.

The ambiguities inherent in ritual practices provide Liking with structural and ideological representation to explore a new concept of gender and freedom aimed at freeing African women from the psychological effects of traditionalism and patriarchal domination they both support. In the ritual process, Ngond Libii is able to reflect 
and see even beyond her mistakes to evoke the entire community’s role in killing Ntep Iliga:

NGOND LIBII: Well, you should start to punish yourselves by burying him. It is you who have killed him and it's a whole vault you need to dig in order to entomb the whole tribe. Are you all not the murderers of Ntep? And he continues to languish.... Murderers! Vampires! It is you who have killed him. You imprisoned him in a carcass which he dragged about throughout his life to protect you and your blasted tribe, your wretched traditions, your monstrous customs, all manner of things whose understanding you lost a long time ago because of laziness and meanness. (Liking, 1996, pp. 38-39)

Ngond Libii's indictment of the community is profound because it is the community's obsequiousness that has led Ntep onto a blind path to self-destruction and using tradition as an alibi. She confronts:

Ah! You well know how you go about it; you start by putting in the head of a poor child that he is God's elect. You use him to serve your vanity; you make him fit into the image of your own creation. You exploit him in the name of tradition. You live on him like parasites, you bleed him to death. (Liking, 1996, p. 39)

Still in the complex of the ritual process Ntep Iliga is resurrected and set into a different consciousness from which he is able to judge the actual motifs of his adulators. As the play progresses, most characters become aware of their unconscious motives and desires, an alteration that leads them to a greater self-awareness of the freedom to accept change.

Liking reveals through the power of performance that gender in Africa is such a complex term and can possibly be grasped effectively through multiple levels of consciousness that only the ritual matrix can provide. Mule (2007, p. 259) has described Liking as "a major, and arguably the most versatile, female force in African letters and art today" who has emerged "as an experimental and authoritative, though controversial, interpreter and defender of the value of the heritage of African traditions in modern literary output”. Dingome (1990, p. 317) also described her as a trend-setter and dramatist with a unique vision, whose drama represents a "major breakaway from current dramatic expression" because of her "innovative ritual aesthetics which steers clear of the prevailing extroversion of contemporary drama". The play ends with a note of reconciliation and with the community's resolution to responsibility: "Who then has killed Ntep? ... May peace come which annihilates hatred, may peace fill our hearts... May love come which engenders Beauty, may love fill our mouths” (Liking, 1996, pp. 59-60).

Thus, The Power of Um draws attention to the funerary practices of the Bassa, but for Liking these rites serve an important new function: righting the wrong within gender formations. Her dramatic style communicates her desire to marry constructive and progressive traditional values to the modern concept of freedom and transformation of gender roles, such that through the power of performance, positive gender relations are created out of the union of the two. This way of anchoring performance on ritual to perform gender makes the plot of The Power of Um to depart from a linear structure to form a cyclical progression of time and action as can be seen in Liking's use of repetition through motifs, chants and gestures. Her use of the dynamics of the ritual matrix then becomes the nexus of the power of performance that collapses the performance of power by male supremacy.

Liking's use of ritual in The Power of Um as a dramatic technique is then motivated by a desire to bridge the gap that separates the artist from the audience, the individual from her or himself, the wielders of power from the subjects against whom such power is wielded, and men and women in their gender relations. There is no better way to mend such chasms than in the totality of the ritual genre where the secular and the sacred, the hallowed 
and the profane can always find a middle ground. The focus of her work alternates between the revival of African aesthetics and culture and a new discourse about the existential material conditions of contemporary African women, or what she calls the aesthetics of necessity:

I would say that my aesthetic is one of necessity. I create my art according to needs, like a cobbler who carries out his work for immediate use. I need to see my dreams materialize. In the beginning, I worked in experimental theater techniques, with ritual, music.... Today, no one knows where to classify me, in terms of an aesthetic. But it's according to the needs of the young people with whom I work. My theater is therefore a vital one: it functions according to the needs of the day. (Mielly, 2003, p. 53)

As an aesthetic choice, ritual for Liking is an important aspect of her authorial ideology, calling attention to the adaptability of African expressive forms and their potential as the ideological basis for renewing the gender landscape. Her aesthetic choices are linked to her purpose: to rediscover, develop, reform and ultimately new gender roles and responsibilities.

In Six Movements, the performance context of The Reign of Wazobia invokes the discursive framework of African cultures casted as the structural frame through which Onwueme reveals how gender identities and subjectivities are formed both within and in opposition to the hegemonic narratives of male supremacist ideologies and of African traditions. Ngugi (2002, p. 38) has insisted that "The main ingredients of performance are space, content, audience, and the goal, whose end so to speak, could be instruction or pleasure, or a combination of both-in short, some sort of reformative effects on the audience”. Through tradition as the structural frame, the dramatist uses the power of performance to incriminate the African audience for its complicity and complacency with hegemonic African traditions and negative gender ideologies. In this respect, the playwright creates a space in which a liberating and transformative narrative can emerge outside the limits of imperial, national, traditional and male supremacist dogmas of identity.

Also, in using tradition as a basis for exploring, exposing and rejecting the injustices that most women go through in the symbolic African society of Anioma, Onwueme's play is largely experimental and she operates her dramatic and performance space outside the normative standards of drama. However, the experimental structural frame serves a purpose as its leaves room for the audience to examine the ideological curves embedded in the play. Onwueme marshals up the Igbo cultural world and its interface with colonial modernity and male supremacy in order to imagine an alternative transformative reality outside Western dominance and African non-progressive traditional ideologies. Her experimental dramatic style is all the more convincing because from both her theoretical reflections and interviews, Onwueme demonstrates a desire to connect her performance space with rural women, "going to the source to speak with—not to talk to—speak with rural women" in order to come up with material for her drama (Becker, 2002, p. 28). Onwueme’s concern articulates the standpoint central to must cultural feminists, the question of voice:

We can lend our voices to or speak up against problems facing others without necessarily speaking for them. We should aim at speaking up with them against the problems and speaking up with them for solutions without speaking against them. (Nnaemeka, 1997, p. 163, emphasis in the original)

According to Onwueme, women have not only been the main victims of un-progressive traditional beliefs and postcolonial challenges; the tragedy is that they have been ignored even when they try to articulate their productive capacities and creative abilities. 
The unconventionality of Onwueme's The Reign of Wazobia is greatly perceived in its stage directions which are as important as what the characters say and do on stage. In conventional drama, stage directions are usually used either to give information about the characters or to help the director manage the set and mise en scene well. But in The Reign of Wazobia, one observes that the stage directions and the speeches of Onwueme's characters in the play form a space in which the spoken and the theorized are blurred. The stage directions then form the important part of the power of performance for they function as authorial and theoretical involvement providing information about the cultural context of the text that would otherwise not be available to the audience and clearing ways for transformative potentials in the performance process.

\section{Conclusion}

This article has tried to demonstrate that Liking and Onwueme in their plays use gender as a site of enactments of power. It has shown that with gender on the agenda, the enactments of power are revealed from two perspectives; the performance of power on women by patriarchal traditional and the power of performance that enacts women's concerns and transform the entire societal fabric through the very power of performance. The study has in turn shown that Liking's and Onwueme's works are thematically ambitious and stylistically experimental given that they are influenced by the tensed historical, cultural, and socio-political conditions of contemporary African women, especially rural women who for the most part are subjects of social change imposed from above. Liking and Onwueme have confirmed Jeyifo’s (2002, p. 464) statement that “Thus African theatrical expressions and traditions which the critical orthodoxy of Western academicism had declared "quasi-theatrical" and "protodramatic" were reappraised in the light of different criteria and affirmed as valid in indigenous traditions of theatrical performance". The arguments have demonstrated that the plays under study constitute innovative integrations of Africa's cultural heritage with modern artistic forms as the playwrights confront the damaging ideologies which keep African women, their men, children and the community in perpetual states of crises, alienation and dependence.

\section{References}

Ajayi, O. (2002). Who can silence her drums. In J. Plastow (Ed.), African theatre: Women (pp. 109-121). Bloomington: Indiana University Press.

Becker, B. (2002). Then She Said It!: An Interview with the Playwright Tess Onwueme. Feminist Teacher, 41(1), 27-40.

Cornwall, A., Harrison, E., \& Whitehead, A. (2004). Gender, development and feminism. IDS Bulletin, 35(4), 1-10.

Dingome, J. (1990). Ritual and modern dramatic expression in Cameroon: The plays of Werewere Liking. In J. Riesz and A. Ricard. (Eds.), Semper Aliquid Novi: Littérature Comparée et Littératures d'Afrique: Melanges Offerts à Albert Gérard (p. 317). Tubingen: Narr.

Gigandi, S. (2002). Introduction. In W. Soyinka (Ed.), Death and the King’s Horseman (Norton Critical Edition). New York: W. W. Norton.

Gunner, E. (1995). Politics of performance: Theatre, poetry and song in Southern Africa. Johannesburg: Witwatersrand University Press.

Kom, A. (1996). Forward. In J. N. Dingone et al. (Ed. \& Trans.), African Ritual Theatre: “The Power of UM” and “A New Earth” (p. 10). San Francisco: International Scholars Publications.

Kruger, L. (1999). The drama of South Africa: Plays pageants and publics since 1910. London: Routledge.

Jeyifo, B. (2002). The invention of theatrical tradition. In B. Jeyifo (Ed.), Modern African drama (pp. 457-468). New York: W. W. Newton.

Liking, W. (1996). The Power of Um. Jean N. Dingone et al., (Ed. \& Trans.). San Francisco: International Scholars Publications. 
March, C., Smyth, I., \& Mukhopadhyay, M. (1999). A guide to gender-analysis framework. Oxfam: Oxfam Publications. Mielly, M. (2003). The aesthetics of necessity: An interview with Werewere Liking. World Literature Today, 52, 52-56. Moore, H. (1995). A passion for difference. Cambridge: Polity.

Mule, K. (2007). Women's spaces, women's visions: Politics, poetics and resistance in African Women's drama. Trenton. NJ: Africa world Press.

Nfah-Abbenyi, M. J. (1997). Gender in African women's writings: Identity, sexuality and difference. Bloomington: Indiana University Press.

Ngugi, W. T. (2002). Enactments of power: The politics of performance space. In B. Jeyifo (Ed.), Modern African drama (pp. 434-456). New York: W. W. Newton.

Nnaemeka, O. (1997). The power of (m)othering in Contemporary African Literature: Womanhood, identity, and resistance in African literature. New York: Routledge.

Ogundipe-Leslie, M. (1994). Re-creating ourselves: African and critical transformation. Trenton, NJ: Africa World Press.

Onwueme, A. T. (1992). The reign of Wazobia and other plays. Ibadon: Heinemann.

Oyewumi, O. (1997). The invention of women: Making an African sense of western gender discourse. Minneapolis: University of Minnesota Press.

Sahli, K. (Ed.). (1998). African theatre for development: Art for self-determination. Exceter, UK: Intellect. Sudarkasa, N. (1986). “The status of women” in indigenous African societies. Feminist Studies, 12(1), 91-103. 